\title{
ANALIZA PARAMETRÓW DETERMINUJĄCYCH STAN NIEPEKNEGO NASYCENIA W GRUNTACH NIESPOISTYCH
}

\author{
Waldemar Świdziński, Marcin Smyczyński ${ }^{\bowtie}$ \\ Instytut Budownictwa Wodnego PAN, Gdańsk
}

\begin{abstract}
STRESZCZENIE
Opis teoretyczny i modelowanie zachowania się gruntu nie w pełni nasyconego wymaga określenia warunku brzegowego, jakim jest faktyczny stan jego nasycenia. W artykule zaprezentowano nowy opis stanu niepełnego nasycenia gruntów wodą, wykorzystujący parametr Skemptona B. W opisie przyjęto makroskopowy model wypełniającego pory gruntu płynu składającego się z wody oraz pęcherzyków powietrza. Na podstawie wyników doświadczeń i rozważań teoretycznych pokazano wpływ ściśliwości mieszaniny wodno-powietrznej wypełniającej pory oraz ściśliwości szkieletu gruntowego na parametr Skemptona B i ich zależność od ciśnienia wyrównawczego i średniego naprężenia efektywnego. Wpływ wymienionych czynników ma szczególne znaczenie w świetle dotychczasowych badań pokazujących, iż w pewnym zakresie nasycenia może dojść również do upłynnienia nie w pełni nasyconego gruntu w stanie kontraktywnym, co stanowi duże zagrożenie dla konstrukcji inżynierskich. Ponadto wykorzystując wyniki pomiarów, opisano związki między prędkością rozchodzenia się fali podłużnej w ośrodku nie w pełni nasyconym a parametrem Skemptona B i stopniem nasycenia.
\end{abstract}

Słowa kluczowe: niepełne nasycenie, parametr Skemptona B, stopień nasycenia, upłynnienie

\section{WSTĘP}

Grunt jest ośrodkiem trójfazowym składającym się ze szkieletu gruntowego, którego pory są wypełnione powietrzem lub wodą. Poszczególne ziarna nie są w nim ze sobą zespolone, a jedynie są powiązane poprzez kontakty wymuszone istniejącym stanem naprężenia. Powszechnie analizuje się i modeluje podłoże jako ośrodek dwufazowy, przyjmując uproszczenie, że jest w pełni nawodniony lub suchy. Przeprowadzone badania wykazują jednak, że już niewielka ilość powietrza w ośrodku nawodnionym może prowadzić do dużych zmian w zachowaniu się gruntu.

Grunty niespoiste mogą w pewnych warunkach podlegać zjawisku upłynnienia. Aby tak się stało, nawodniony ośrodek gruntowy musi znajdować się w stanie kontraktywnym, czyli dążyć do zagęszcza- nia się przy ścinaniu. $\mathrm{W}$ wyniku ścinania takiego ośrodka w warunkach bez odpływu wody z porów następuje zwiększenie się ciśnienia porowego, a gdy zrówna się ono ze średnim naprężeniem całkowitym, dochodzi do utraty kontaktu między ziarnami i w konsekwencji do upłynnienia gruntu, czyli redukcji średniego naprężenia efektywnego do zera (Świdziński, 2006; Sawicki, 2012). Grunt zamienia się wówczas w gęstą lepką ciecz, stanowiąc olbrzymie zagrożenie dla posadowionych na nim konstrukcji. Do niedawna analizowano upłynnienie gruntów, zakładając ich pełne nasycenie. Prowadzone w ostatnich latach badania laboratoryjne dowiodły jednak, że stan niepełnego nasycenia jedynie zmniejsza podatność gruntu na upłynnienie (Okamura i Soga, 2006; Della i Arab, 2010; Świdziński, Mierczyński i Smyczyński, 2018).

${ }^{\varpi_{m} . s m y c z y n s k i @ i b w p a n . g d a . p l}$ 
Zagadnienie związku między stanem nasycenia wodą a podatnością gruntu na upłynnienie pozostawia do dziś pole do odrębnych badań i analiz (Fredlund, Rahardjo i Fredlund, 2012). Problemem okazuje się już sam opis stanu nasycenia ośrodka trójfazowego i właściwe uwzględnienie $\mathrm{w}$ nim znajdującego się w porach powietrza. W warunkach laboratoryjnych określenie stopnia nasycenia próbki przygotowywanej do badań trójosiowego ściskania jest niezwykle trudne, w praktyce można stosować tylko pewne oszacowania. Pomocny w tym zakresie jest zaproponowany przez Skemptona parametr B (Skempton, 1954), wyrażający, jak duża część izotropowego ciśnienia przyłożonego do próbki jest przejmowana przez uwięzioną w porach wodę. Za w pełni nasycony powszechnie uznaje się ośrodek o $\mathrm{B} \geq 0,96$, a standardowy pomiar jest zazwyczaj wykonywany na początku badania przy małej wartości średniego naprężenia efektywnego. Stosowanie parametru Skemptona jest wygodne, jednak podczas badań gruntów nie w pełni nasyconych trzeba znać poziomy ciśnienia zewnętrznego, przy których przeprowadzano pomiar, i należy mieć świadomość tego, że w zależności od nich ta sama wartość parametru Skemptona B może reprezentować różne rzeczywiste stany nasycenia.

$\mathrm{Z}$ inżynierskiego punktu widzenia istotne jest, aby parametry ośrodka gruntowego wykorzystywane w modelowaniu mogły być wyznaczane w sposób efektywny, jednoznaczny i wiarygodny (Jastrzębska i Kalinowska-Pasieka, 2015). Temu właśnie celowi służyć ma przedstawione $\mathrm{w}$ artykule skorelowanie charakterystyki nasycenia gruntu z wynikami badań sejsmicznych in situ, poprzez parametry takie jak np. prędkość rozchodzenia się fali podłużnej.

\section{OPIS TEORETYCZNY}

\section{Fizyczna interpretacja parametru Skemptona B}

Parametr Skemptona B opisuje zmiany ciśnienia wody W porach $(\Delta u)$ w wyniku izotropowego ściskania próbki gruntu poprzez zwiększanie ciśnienia wody w komorze trójosiowej $\left(\Delta \sigma_{3}\right)$ w warunkach bez drenażu, czyli:

$$
\mathrm{B}=\frac{\Delta u}{\Delta \sigma_{3}}
$$

Upłynnieniem zagrożone są jedynie grunty niespoiste, w których zawartość powietrza w porach gruntu stanowi niewielką domieszkę w stosunku do objętości wody wypełniającej pory ośrodka nie w pełni nasyconego. W takiej sytuacji różnice ciśnień powietrza i wody w porach są zaniedbywalnie małe (Bian i Shahrour, 2009), dlatego też w poniższych analizach ciśnienie ssania nie będzie brane pod uwagę.

W warunkach bez odpływu wody z porów wzrost ciśnienia porowego jest wywołany dążeniem struktury szkieletu do zagęszczania się, zablokowanym przez uwięzioną w porach wodę, co można wyrazić następującymi wzorami:

$$
\begin{gathered}
\Delta V=\kappa_{s} V \Delta \sigma_{3}^{\prime} \\
\Delta V_{p}=\kappa_{f} n V \Delta u
\end{gathered}
$$

gdzie: $\Delta V-$ zmiany objętości szkieletu gruntowego występujące w gruncie suchym,

$\Delta V_{p}$ - zmiany objętości porów występujące w gruncie suchym,

$V$ - objętość gruntu,

$\kappa_{s}-$ ściśliwość szkieletu gruntowego,

$\kappa_{f}-$ ściśliwość cieczy wypełniającej pory gruntowe,

$\Delta \sigma_{3}^{\prime}$ - naprężenie efektywne równe średniemu naprężeniu efektywnemu $\left(p^{\prime}\right)$,

n - porowatość.

Przyjmując ziarna szkieletu za nieściśliwe $\left(\kappa_{\text {ziaren }}\right.$ $<<\kappa_{s}$ ), zmiana objętości szkieletu gruntowego i zmiana objętości porów są sobie równe:

$$
\Delta V_{p}=\Delta V
$$

Podstawienie związku:

$$
\Delta \sigma_{3}=\Delta \sigma_{3}{ }^{\prime}+\Delta u
$$

do wzoru (1) oraz uwzględnienie zależności (2), (3) i (4) uzasadnia wniosek, iż parametr Skemptona B jest funkcją ściśliwości płynu porowego i szkieletu gruntowego:

$$
\mathrm{B}=\frac{1}{1+\frac{n \kappa_{f}}{\kappa_{s}}}=f\left(\kappa_{s}, \kappa_{f}\right)
$$


W warunkach pełnego nasycenia gruntu $\left(S_{r}=1\right)$ zakłada się brak zmian jego objętości $\left(\kappa_{f}<<\kappa_{s}\right)$, co skutkuje tym, że B $=1$.

\section{Wpływ ciśnienia wyrównawczego}

Na bazie klasycznej definicji ściśliwości płynów można zapisać, że ściśliwość mieszaniny wodno-powietrznej zawartej w porach wyraża się wzorem (Verruijt, 1969):

$$
\kappa_{f}=\left(1-S_{r}\right) \kappa_{\alpha}+S_{r} \kappa_{w}
$$

gdzie: $S_{r}$ - stopień nasycenia,

$\kappa_{\alpha}$ - ściśliwość powietrza zawartego w porach,

$\kappa_{w}-$ ściśliwość wody w porach.

Ściśliwość wody w porach gruntu jest bardzo mała $\left(k_{w}=0,45 \cdot 10^{-6} \mathrm{kPa}=\right.$ const $)$ i nieznacznie zależy od zmian ciśnienia. Zakłada się, że temperatura nie wpływa na gaz zawarty w porach, wobec czego ściśliwość powietrza $\mathrm{w}$ porach może być opisywana zależnością (8) wynikającą z równania gazu doskonałego (Świdziński i in., 2018).

$$
\kappa_{a}=\frac{1}{u_{a}}
$$

gdzie $u_{a}-$ ciśnienie powietrza (należy pamiętać, że $u_{a}=u+u_{\text {atm }}$ jest tutaj rozumiane jako ciśnienie całkowite).

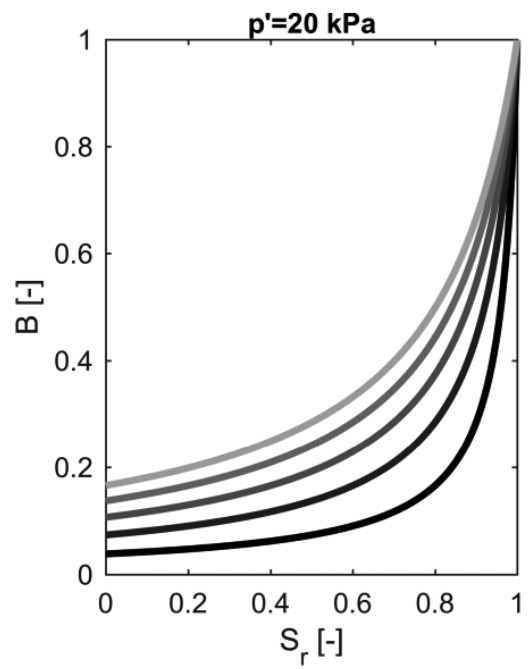

Ciśnienie powietrza zawartego $\mathrm{w}$ porach poprzez zależności (7) i (8) wpływa na ściśliwość płynu w porach, a poprzez nią, zgodnie z zależnością (6), determinuje wartość parametru Skemptona B.

W badaniach laboratoryjnych pomiaru B dokonuje się zwykle w warunkach małego, stałego i powtarzalnego stanu naprężenia ( $p^{\prime} \cong 20 \mathrm{kPa}$ ). Chcąc uzyskać stan pełnego nasycenia, stosuje się technikę podnoszenia ciśnienia wyrównawczego do takiej wartości, przy której parametr Skemptona B jest bliski jedności. Dla ośrodków w pełni nasyconych, gdy $\kappa_{f} \approx \kappa_{w}$, zmiany ściśliwości wywołane przyrostami ciśnienia wyrównawczego są zaniedbywalnie małe, jednak w warunkach niepełnego nasycenia dla określenia stopnia nasycenia niezbędne jest stosowanie wzoru (9) otrzymanego poprzez podstawienie równania (7) do (6) i odpowiednie przekształcenia algebraiczne:

$$
S_{r}=\frac{\frac{\kappa_{s}}{n}\left(\frac{1}{\mathrm{~B}}-1\right) \kappa_{a}}{\kappa_{w}-\kappa_{a}}
$$

Na podstawie wzoru (9) na rysunku 1 przedstawiono odwróconą zależność B i $S_{r}$ dla różnych wartości ciśnienia wyrównawczego $\left(u_{b}\right)$ oraz dwóch wartości $p^{\prime}=20$ i $p^{\prime}=200 \mathrm{kPa}$, przy czym wartości $\kappa_{s}$ przyjęto

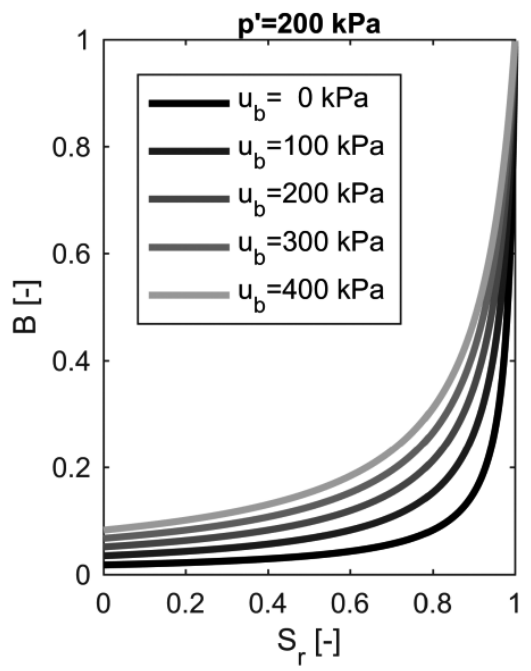

Rys. 1. Zależność wartości parametru Skemptona B od stopnia nasycenia $\left(S_{r}\right)$ dla różnych wartości ciśnienia wyrównawczego $\left(u_{b}\right)$

Fig. 1. Relationships of the Skempton's coefficient B on the degree of saturation $\left(S_{r}\right)$ for different levels of the back pressure $\left(u_{b}\right)$ 
jako typowe dla gruntów opisanych w następnym rozdziale dotyczącym badań laboratoryjnych.

\section{Wpływ średniego naprężenia efektywnego}

Ścinanie gruntu w warunkach trójosiowych poprzedzane jest najczęściej fazą izotropowej lub anizotropowej konsolidacji, w wyniku której następuje zmniejszenie się ściśliwości ośrodka gruntowego. W gruntach nie w pełni nasyconych powoduje to zmniejszenie się mierzonej przed fazą konsolidacji wartości parametru Skemptona B.

Ściśliwość szkieletu gruntowego jest funkcją średniego naprężenia efektywnego, będąc równocześnie pochodną zmian objętościowych przy izotropowym ściskaniu (dla gruntu suchego lub nawodnionego $\mathrm{z}$ możliwością odpływu wody z porów). Ze wzoru (2) wynika, że:

$$
\kappa_{s}=\frac{d \varepsilon_{v}^{s}}{d p^{\prime}}
$$

Odkształcenia objętościowe $d \varepsilon_{v}^{s}$ podczas izotropowego ściskania $d p^{\prime}$ wykazują największą zmienność w początkowych fazach obciążenia, analogicznie wy- stępować będą najintensywniejsze zmiany ściśliwości (bezpośrednio po przekroczeniu wartości $p^{\prime}=20 \mathrm{kPa}$, przy której najczęściej dokonuje się pomiaru parametru Skemptona B).

Korzystając ponownie ze wzoru (9), na rysunku 2 pokazano wpływ średniego naprężenia efektywnego na relację między B a $S_{r}$, dla dwóch wartości $u_{b}=0$ i $u_{b}=300 \mathrm{kPa}$.

\section{Przebieg zmian nasycenia}

W przypadku gruntów niespoistych badania w warunkach trójosiowego ściskania sa przeprowadzane na próbkach rekonstruowanych. Formowane są one najczęściej w stanie powietrzno-suchym lub przy wilgotności oscylującej wokół $2 \%$ (np. dla metody podzagęszczania), a dopiero później nawadniane do osiagnięcia żądanej wartości parametru Skemptona B. Przykładowe teoretyczne zmiany wartości parametru Skemptona B i stopnia nasycenia dla różnych wartości początkowego nasycenia $\mathrm{w}$ fazach badania poprzedzających przyłożenie dewiatora naprężenia przedstawiają rysunki 3 i 4 . W przypadku gruntów nie w pełni nasyconych istotne znaczenie dla zachowania się parametru Skemptona B (jego zmniejszenia) mają
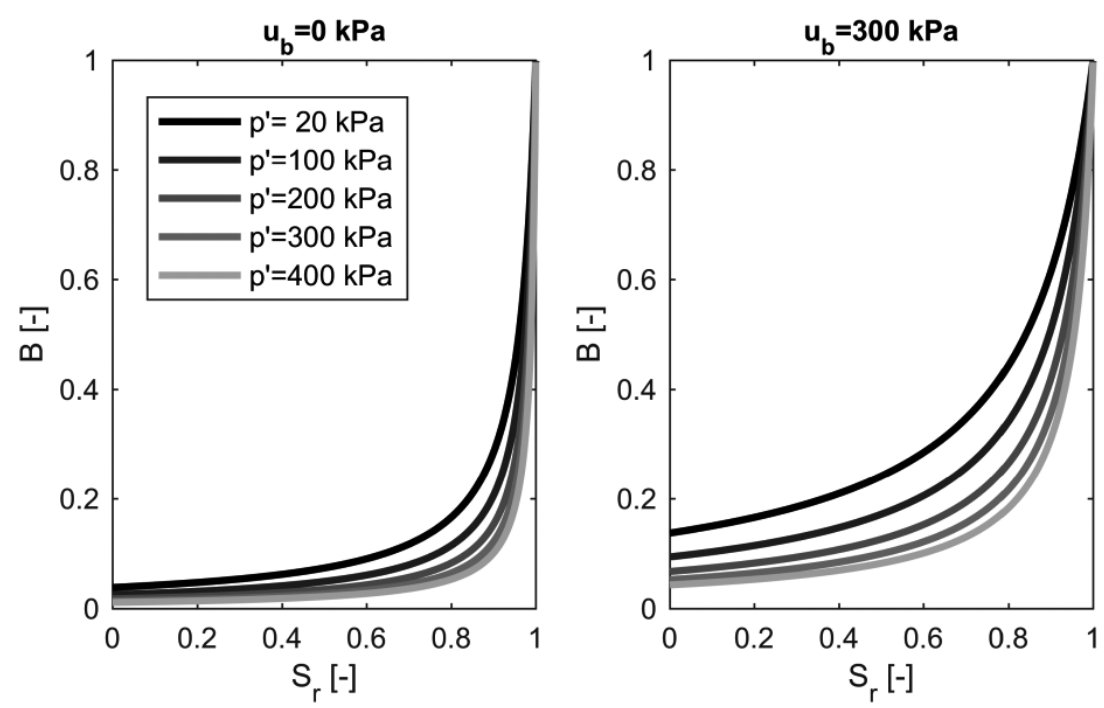

Rys. 2. Zależność wartości parametru Skemptona B od stopnia nasycenia $\left(S_{r}\right)$ dla różnych wartości średniego naprężenia efektywnego $\left(p^{\prime}\right)$

Fig. 2. Relationships of the Skempton's coefficient B on the degree of saturation $\left(S_{r}\right)$ for different values of mean effective stress $\left(p^{\prime}\right)$ 
Świdziński, W., Smyczyński, M. (2018). Analiza parametrów determinujących stan niepełnego nasycenia w gruntach niespoistych. Acta Sci. Pol. Architectura, 17 (2), 3-13. doi: 10.22630/ASPA.2018.17.2.10

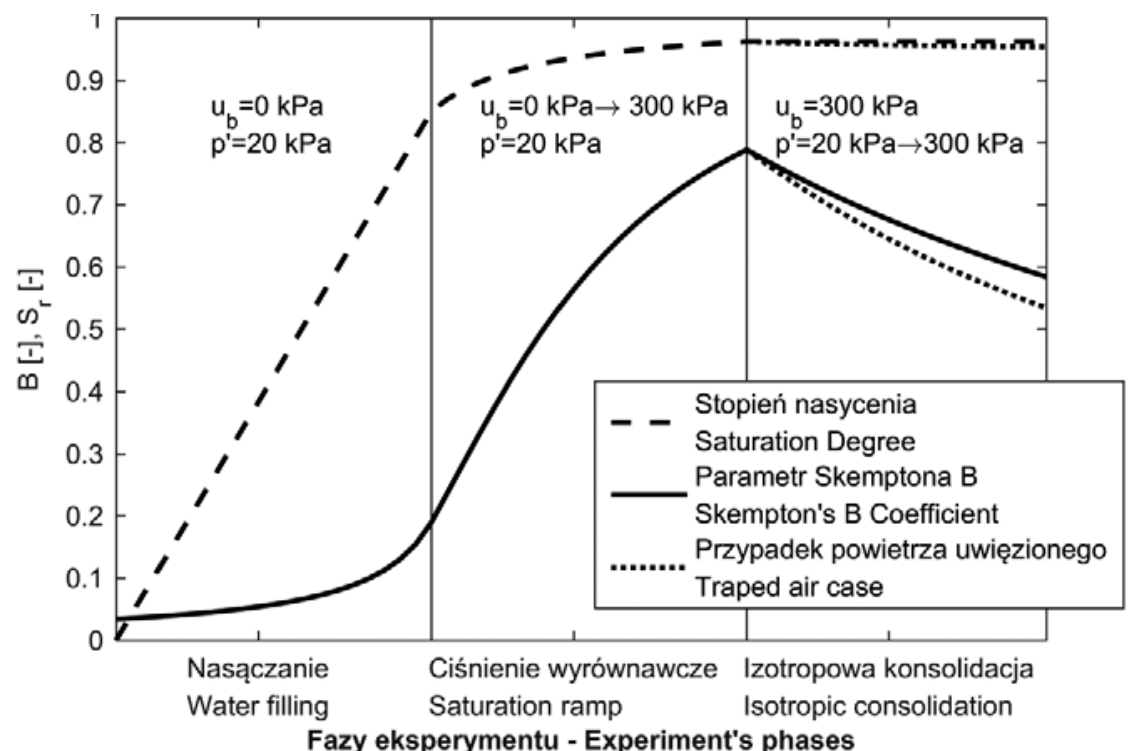

Rys. 3. Zmiany stanu nasycenia w poszczególnych fazach doświadczenia. Większe nasycenie początkowe $\left(\mathrm{S}_{r, 0}=0,85\right)$

Fig. 3. Saturation changes in individual phases of the experiment. Higher initial saturation $\left(\mathrm{S}_{r, 0}=0.85\right)$

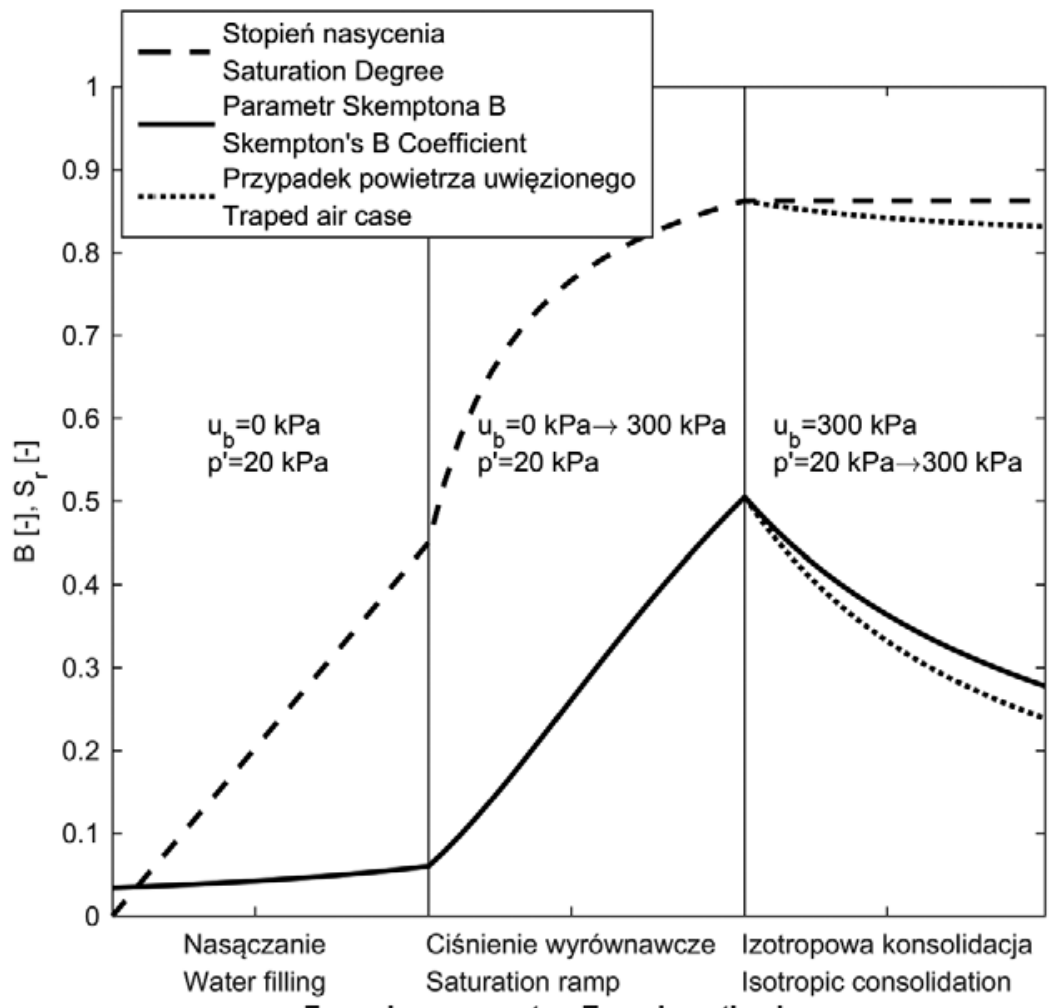

Fazy eksperymentu - Experiment's phases

Rys. 4. Zmiany stanu nasycenia w poszczególnych fazach doświadczenia. Mniejsze nasycenie początkowe $\left(\mathrm{S}_{r, 0}=0,45\right)$

Fig. 4. Saturation changes in individual phases of the experiment. Lower initial saturation $\left(\mathrm{S}_{r, 0}=0.45\right)$ 
zmiany zachodzące w ostatniej fazie, czyli izotropowej konsolidacji. Linią kropkowaną zaznaczono przebiegi zakładające uwięzienie pęcherzyków powietrza w gruncie (w wyniku konsolidacji z porów odpływa jedynie woda). W każdym $\mathrm{z}$ przypadków obserwowane jest zmniejszenie się parametru Skemptona B, które jest tym wyraźniejsze, im mniej nasycony był analizowany ośrodek.

\section{BADANIA LABORATORYJNE}

\section{Zmiany parametru Skemptona B podczas izotropowej konsolidacji}

W celu weryfikacji założeń przedstawionych w poprzednim rozdziale przeprowadzono badania izotropowego ściskania na rekonstruowanych próbkach o kontrolowanym nasyceniu. Badania przeprowadzono w aparacie trójosiowego ściskania firmy GDS Instruments Ltd. wyposażonym w lokalne czujniki przemieszczeń, niezbędne do pełnej kontroli początkowego wskaźnika porowatości oraz jego zmian w trakcie badania, od momentu instalacji próbki w aparacie trójosiowym. Do tego celu wykorzystywane są lokalne czujniki przemieszczeń poziomych i pionowych typu Halla, instalowane na próbce o wymiarach $38 \times 80 \mathrm{~mm}$, bezpośrednio po jej uformowaniu (Świdziński, 2006). Jako materiału do badań użyto pomiedziowych osadów poflotacyjnych OZM50 o następujących parametrach fizycznych:

- $\rho_{s}=2,675 \mathrm{~g} \cdot \mathrm{cm}^{-3}$,

- $\rho_{\min }=1,32 \mathrm{~g} \cdot \mathrm{cm}^{-3}$

- $\rho_{\max }=1,63 \mathrm{~g} \cdot \mathrm{cm}^{-3}$,

$-e_{\min }=0,643$,

$-e_{\max }=1,026$,

- $d_{50}=0,157 \mathrm{~mm}$,

- $5,8 \%$ ziaren o $d<0,075$,

- $S F R=15,67$.

W czasie badania mierzono zmiany wartości parametru Skemptona B w funkcji ciśnienia konsolidującego $\left(\sigma_{3}{ }^{\prime}=p^{\prime}\right)$. Wyniki badań wraz z krzywą teoretyczną określona na podstawie wzoru (6) i wartości $\kappa_{s}$, wyznaczonej w testach izotropowej konsolidacji (z pomiarem odkształceń objętościowych), przedstawiono na rysunkach 5 i 6 , odpowiednio dla dużych wartości parametru Skemptona B (test ms10) i małych wartości (test ms07).

$\mathrm{Na}$ wykresach pokazanych na rysunkach 5 i 6 widać, że w trakcie izotropowej konsolidacji następuje wyraźne zmniejszanie się wartości parametru Skemptona B wraz ze zwiększaniem się średniego naprężenia efektywnego.

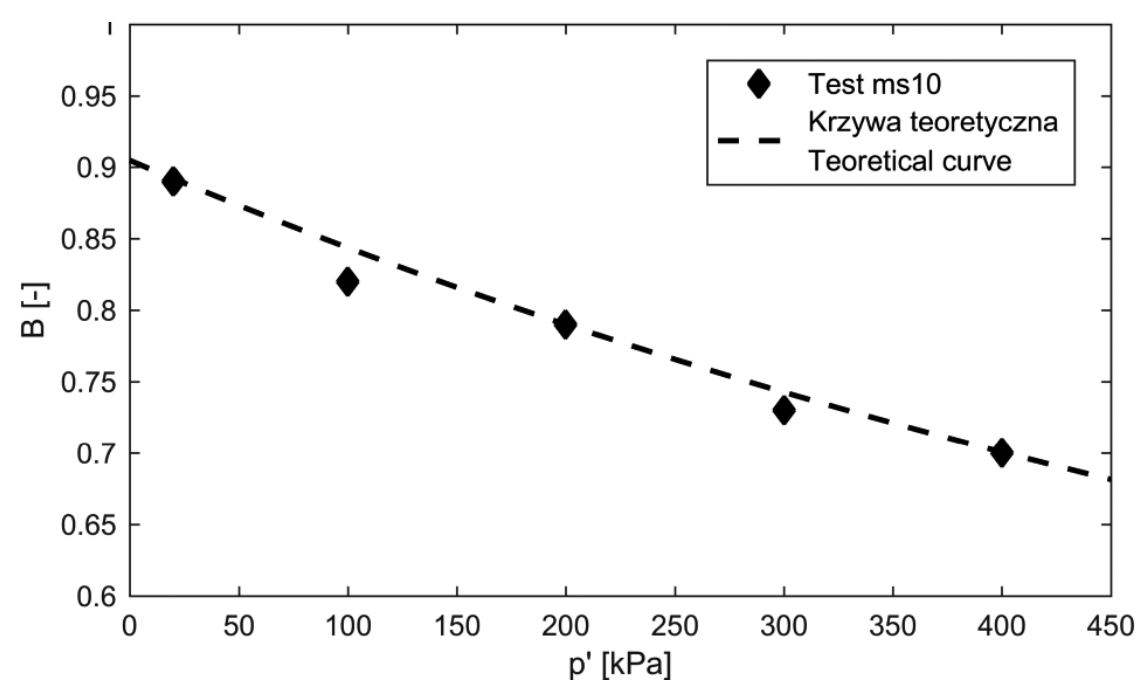

Rys. 5. Zmiana wartości parametru Skemptona B wraz ze średnim naprężeniem efektywnym (test ms 10)

Fig. 5. Change of Skempton's coefficient B value with mean effective stress (test ms10) 


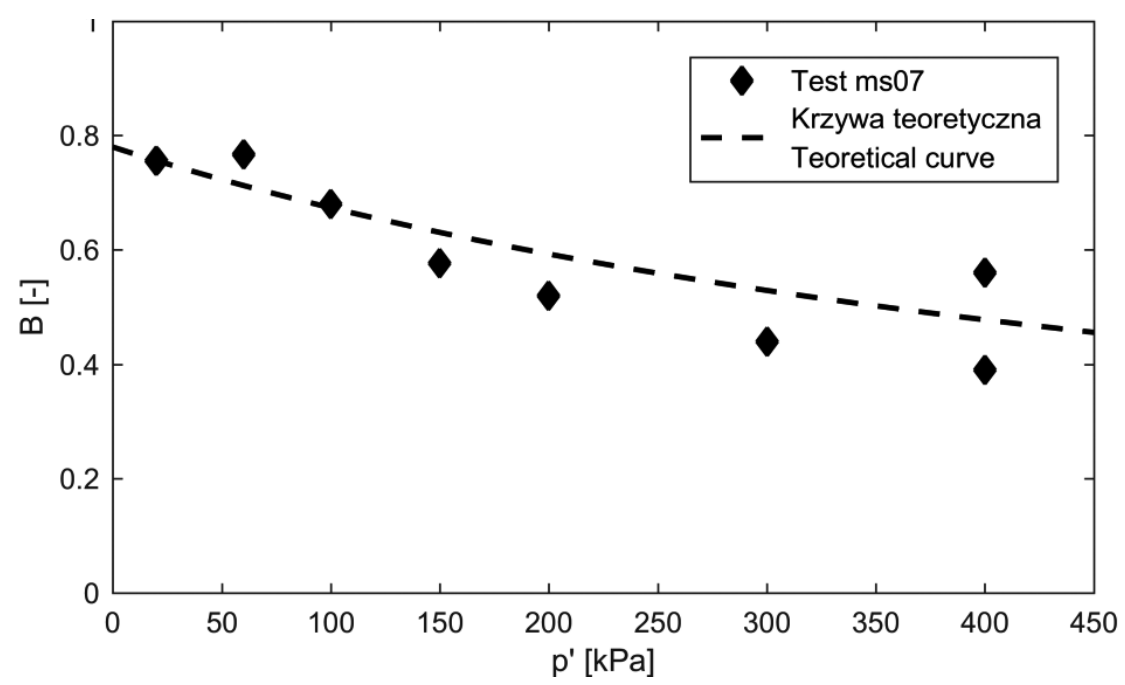

Rys. 6. Zmiana wartości parametru Skemptona B wraz ze średnim naprężeniem efektywnym (test ms07)

Fig. 6. Change of Skempton's coefficient B value with mean effective stress (test ms07)

\section{Korelacja stanu nasycenia z prędkością rozchodzenia się fali podłużnej}

Aby móc wykorzystać wyniki badań laboratoryjnych w praktyce, istotna jest ich weryfikacja polegająca na identyfikacji stanu nasycenia podłoża gruntowego w warunkach in situ. Do tego celu bardzo przydatne mogą być pomiary prędkości przejścia fali podłużnej metodami międzyotworowymi (ang. cross-hole). W warunkach pełnego nasycenia prędkość rozchodzenia się fali podłużnej $\mathrm{w}$ gruncie jest zbliżona do prędkości rozchodzenia się dźwięku w wodzie $\left(v_{p} \simeq 1500 \mathrm{~m} \cdot \mathrm{s}^{-1}\right)$. Wraz ze zmniejszaniem się stopnia nasycenia również zmniejsza się prędkość rozchodzenia się fali podłużnej (Świdziński, Mierczyński i Mikos, 2017).

Na rysunku 7 przedstawiono przykładowe wyniki badań cross-hole wykonane w podłożu, w którym występują nawodnione osady poflotacyjne $\mathrm{w}$ formie piasków drobnych i pylastych. Woda wypełniająca pory osadów poflotacyjnych ze względu na silne zasolenie charakteryzuje się dużą prędkością rozchodzenia się fal podłużnych, osiągającą nawet ponad $1600 \mathrm{~m} \cdot \mathrm{s}^{-1}$. Nawiercone zwierciadło wody znajdowało się na głębokości $11 \mathrm{~m}$ p.p.t. Charakterystyczny skok prędkości rozchodzenia się fali $\left(\operatorname{do~} v_{p}=1600 \mathrm{~m} \cdot \mathrm{s}^{-1}\right)$ na głębokości $21 \mathrm{~m}$ p.p.t. świadczy o tym, że dopiero tam rozpoczyna się strefa pełnego nasycenia.
W celu identyfikacji podobnego zjawiska w laboratorium oraz korelacji prędkości fali podłużnej ze stopniem nasycenia i parametrem Skemptona B przeprowadzono badania laboratoryjne $\mathrm{w}$ aparacie trójosiowego ściskania. Tym razem badania przeprowadzono $\mathrm{w}$ innym aparacie trójosiowego ściskania firmy Enel-Hydro wyposażonym w elementy piezoelektryczne umożliwiające pomiar prędkości rozchodzenia się fal podłużnych i poprzecznych w badanej próbce (Świdziński, 2006). Ponadto ten aparat jest wyposażony w lokalne czujniki przemieszczeń typu zbliżeniowego. Przeprowadzone badania polegały na pomiarze prędkości rozchodzenia się podłużnej fali sejsmicznej dla różnych wartości stopnia nasycenia, które otrzymywano poprzez zwiększanie ciśnienia wyrównawczego. Rysunki 8 i 9 przedstawiają wyniki doświadczeń dla średnich i dużych początkowych wartości stopnia nasycenia. W pierwszym przypadku (test ms12) badanie obejmowało również początkową fazę, w której próbka była nasączana wodą i niemożliwe było dokładne określenie stopnia nasycenia. W obu badaniach utrzymywano średnie naprężenie efektywne na poziomie $p^{\prime}=20 \mathrm{kPa}$.

Wyniki doświadczeń wskazują, że istotnie gwałtowne zwiększenie się wartości prędkości przejścia fali podłużnej towarzyszy osiągnięciu stopnia nasycenia bliskiego jedności. W zakresie małych wartości stopnia nasycenia zakres zmian prędkości fali jest niewielki. 

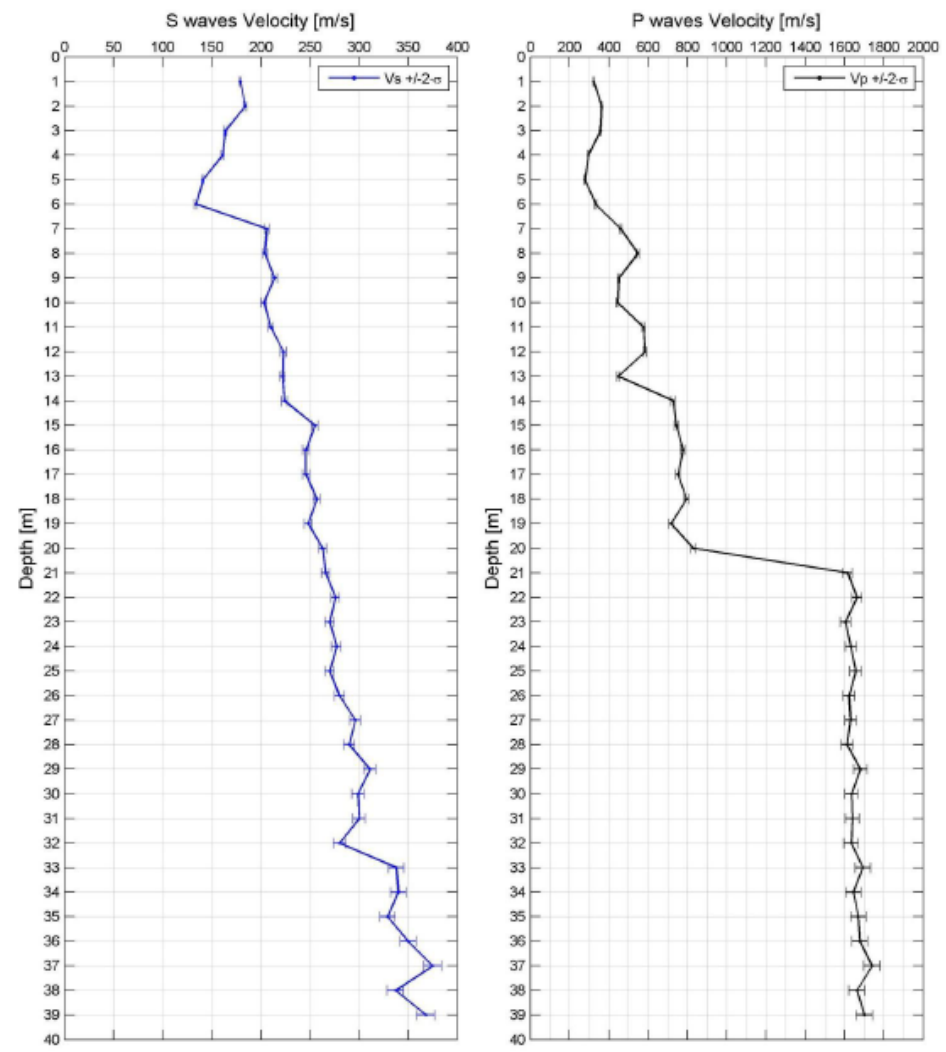

Rys. 7. Prędkości przejścia fal sejsmicznych w warunkach in situ (Świdziński i in., 2017)

Fig. 7. In situ velocities of the seismic waves (Świdziński et al., 2017)

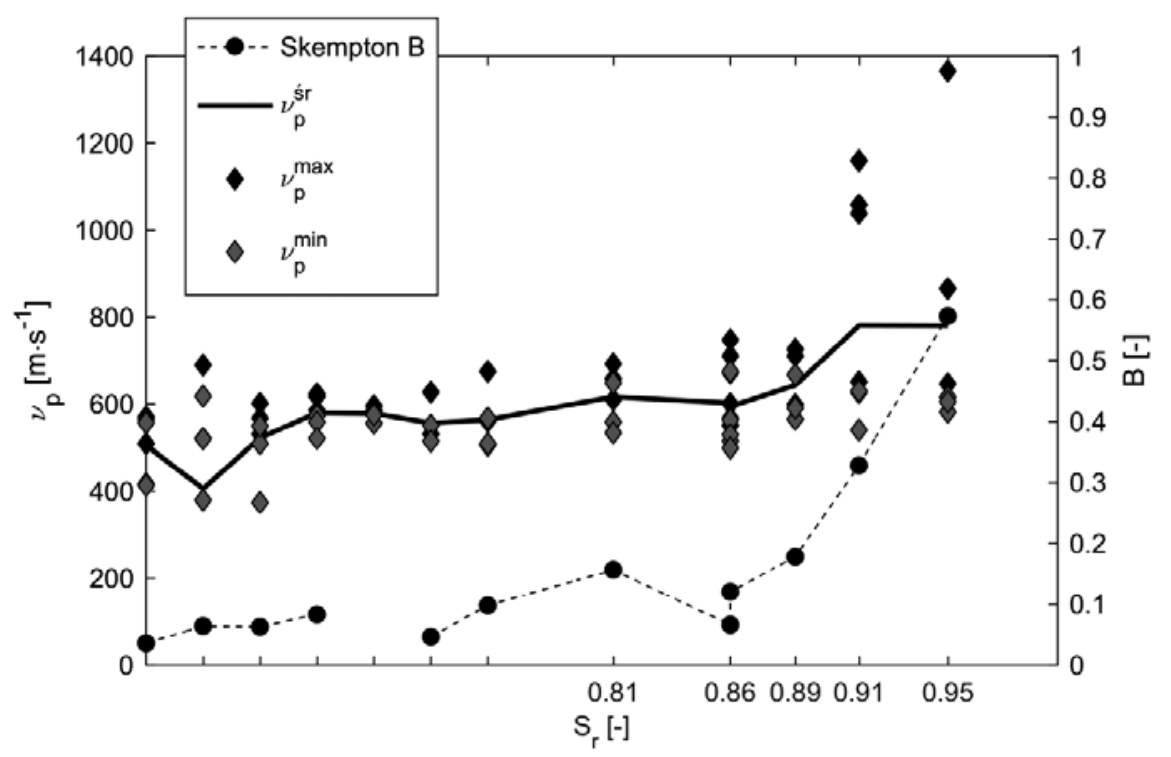

Rys. 8. Prędkość rozchodzenia się fali podłużnej dla średnich początkowych wartości $S_{r}$ (test ms12)

Fig. 8. Velocity of longitudinal wave propagation for medium initial value of $S_{r}$ (test ms 12) 


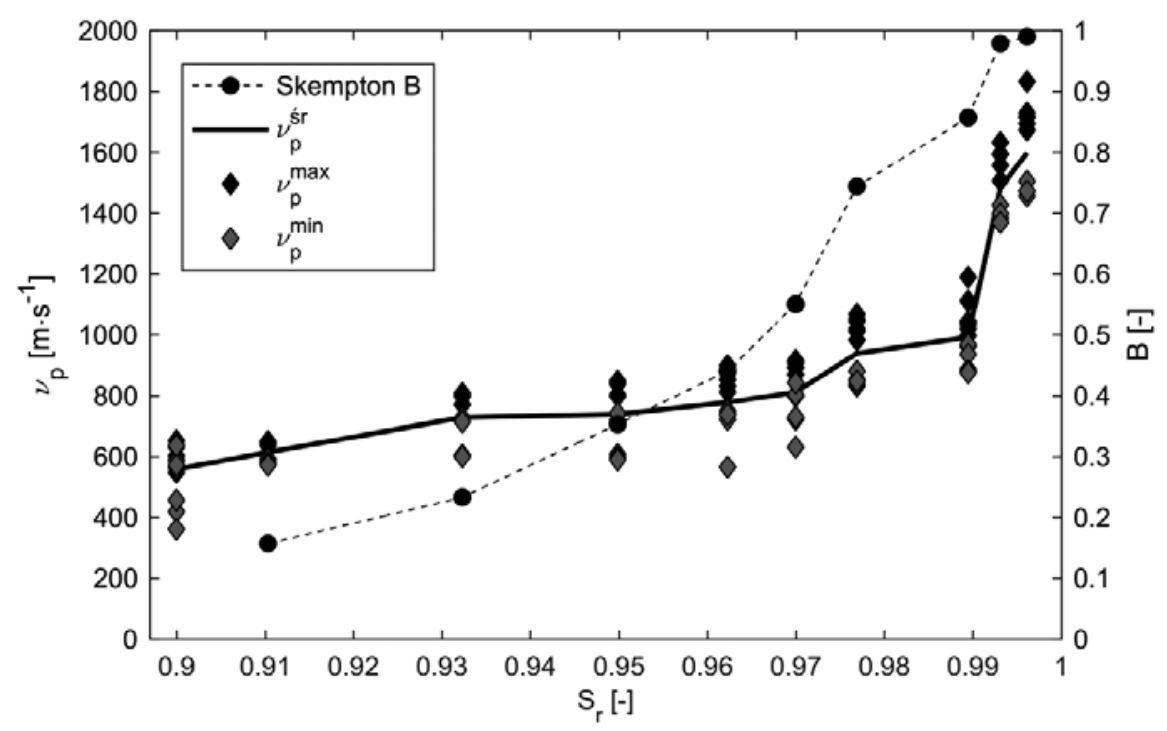

Rys. 9. Prędkość rozchodzenia się fali podłużnej dla wysokich początkowych wartości $S_{r}$ (test ms 13)

Fig. 9. Velocity of the longitudinal wave propagation for high initial values of $S_{r}$ (test ms13)

Analogiczna sytuacja zachodzi dla relacji prędkości rozchodzenia się fali podłużnej i parametru Skemptona B (rys. 10).

Wyniki badań pokazane na rysunku 10 aproksymowano metodą najmniejszych kwadratów funkcją trygonometryczną arc tan o postaci:

$$
\mathrm{B}\left(v_{p}\right)=a_{1} \arctan \left(a_{2} v_{p}+a_{3}\right)+a_{4}
$$

gdzie: $a_{1}=0,33445$,

$a_{2}=0,010494$,

$a_{3}=-8,4017$,

$a_{4}=0,505$.

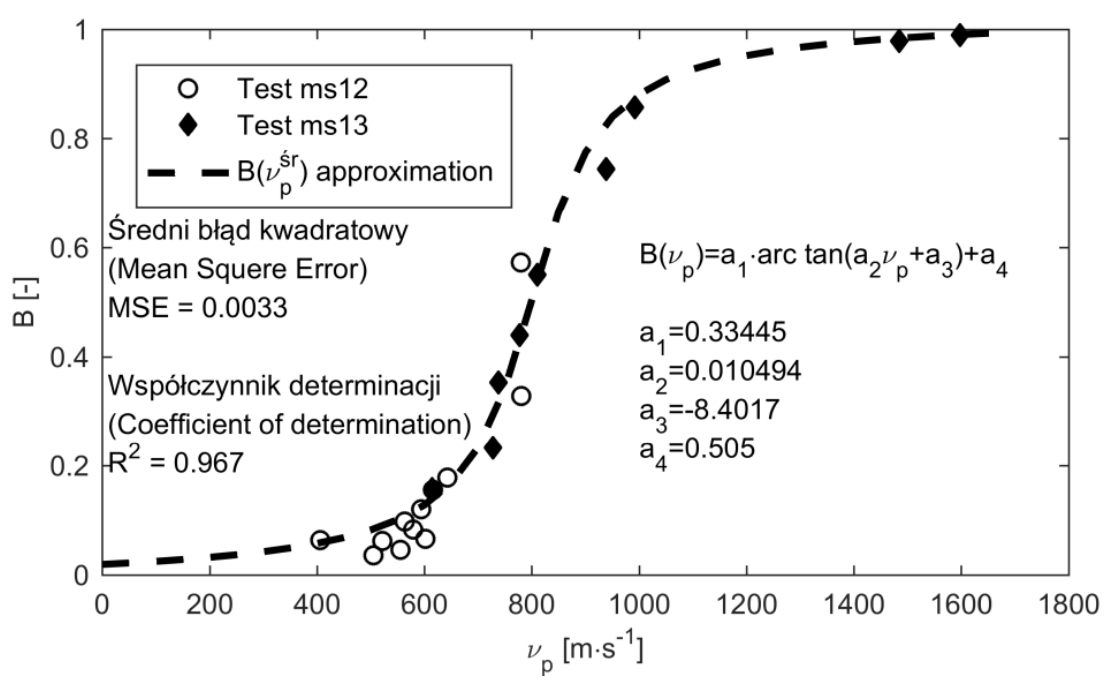

Rys. 10. Aproksymacja zmian parametru Skemptona B wraz z prędkością fali podłużnej

Fig. 10. Approximation of changes in Skempton's coefficient B with the longitudinal wave velocity 
Liczbę parametrów w funkcji (11) można zmniejszyć kosztem niewielkiej utraty dokładności, przyjmując $\mathrm{w}$ miejsce parametrów $a_{1}$ i $a_{4}$ stałe wartości odpowiednio $1 / \pi$ i 0,5 wynikające $z$ analitycznych przekształceń funkcji arctan.

\section{PODSUMOWANIE I WNIOSKI}

Badania, których wyniki przedstawiono $\mathrm{w}$ niniejszym artykule, pokazały, że dla gruntu niespoistego $\mathrm{w}$ stanie niepełnego nasycenia określony parametr Skemptona B należy analizować w odniesieniu do stanu naprężenia, przy którym został pomierzony. Duży wpływ na wartość parametru Skemptona B mają ciśnienie wyrównawcze (poprzez swój wpływ na ściśliwość mieszaniny wodno-powietrznej) oraz średnie naprężenie efektywne determinujące ściśliwość szkieletu gruntowego (rozumianą jako ściśliwość jego struktury przestrzennej, a nie poszczególnych ziaren).

W zakresie niepełnego nasycenia możliwa jest sytuacja, w której tej samej wartości Skemptona B odpowiadają zależnie od stanu naprężenia różne stopnie nasycenia. Powyższy wniosek ma szczególne znaczenie w badaniach trójosiowych nawodnionych gruntów niespoistych w warunkach bez odpływu wody z porów oraz modelowaniu reakcji na obciążenie takich gruntów w stanie niepełnego nasycenia.

Najbardziej pożądaną informacją przy teoretycznym modelowaniu zachowania się gruntów nie w pełni nasyconych jest ich stopień nasycenia. Do jego wyznaczenia na podstawie parametru Skemptona B niezbędna jest znajomość ściśliwości szkieletu gruntowego, porowatości ośrodka oraz ciśnienia panującego w jego porach (lub aktualnej ściśliwości płynu porowego).

Parametr Skemptona B dla danego gruntu można skorelować z prędkością rozchodzenia się w nim fali podłużnej. Pozwala to na określenie stopnia nasycenia gruntu zalegającego w podłożu na podstawie pomierzonych metodami in situ wartości prędkości przejścia fali, a także geostatycznego rozkładu naprężeń, ciśnienia porowego panującego w ośrodku oraz ściśliwości szkieletu danego gruntu.

\section{PIŚMIENNICTWO}

Bian, H. i Shahrour, I. (2009). Numerical model for unsaturated sandy soils under cyclic loading: Application to liquefaction. Soil Dynamics and Earthquake Engineering, 29(2), 237-244.

Della, N. i Arab, A. (2010). Laboratory Investigation on the Saturation and Initial Structure Effects on the Undrained Behavior of Granular Soil Under Static Loading. Acta Polytechnica Hungarica, 7(5), 143-160.

Fredlund, D. G., Rahardjo, H. i Fredlund, M. D. (2012). Unsaturated Soil Mechanics in Engineering Practice. Hoboken: John Wiley \& Sons.

Jastrzębska, M. i Kalinowska-Pasieka, M. (2015). Wybrane metody badawcze we wspótczesnym laboratorium geotechnicznym: od podłoża do parametrów gruntowych. Gliwice: Wydawnictwo Politechniki Śląskiej.

Okamura, M. i Soga, Y. (2006). Effects of Pore Fluid Compressibility on Liquefaction Resistance of Partially Saturated Sand. Soils and Fundations, 46(5), 695-700.

Sawicki, A. (2012). Zarys mechaniki gruntów sypkich. Gdańsk: IBW PAN.

Skempton, A. (1954). The Pore-pressure Coefficients A and B. Géotechnique, 4(4), 143-147.

Świdziński, W. (2006). Mechanizmy zagęszczania i uptynniania gruntów sypkich. Gdańsk: IBW PAN.

Świdziński, W., Mierczyński, J. i Mikos, A. (2017). Response of partially saturated non-cohesive soils. Archives of Hydro-Engineering and Environmental Mechanics, 64(3-4), 187-207.

Świdziński, W., Mierczyński, J. i Smyczyński, M. (2018). Modelling of the response of partially saturated noncohesive soil subjected to undrained loading. Archives of Hydro-Engineering and Environmental Mechanics 65(1), 11-29.

Verruijt, A. (1969). Elastic storage of aquifers. W R. J. De Wiest (red.), Flow through porous media (strony 331-376). New York: Academic Press. 


\title{
ANALYSIS OF INFLUENCE OF PARAMETERS DETERMINING THE PARTIALLY SATURATION CONDITIONS IN NON-COHESIVE SOILS
}

\begin{abstract}
Theoretical description and modeling of the behavior of the partially saturated soils requires determination of their real saturation. The paper presents the method how to describe partial saturation, using the Skempton's coefficient B. In the considerations macroscopic description of the fluid consisting of water with air bubbles filling the pores of soil was implemented. On the basis of the experiments and theoretical background, the effect of compressibility of the water and air mixture and compressibility of the soil skeleton on the Skempton's coefficient B as well as their dependence on back pressure and mean effective stress were shown. The above is of significant importance in the light of previous studies showing that at some range of saturation the liquefaction phenomenon could occurred in partially saturated soils as well expanding the threat to engineering structures. Moreover, based on the results of measurements, an attempt was made to describe the relationship between the longitudinal wave velocity in the partially saturated medium, the Skempton's coefficient B and the degree of saturation.
\end{abstract}

Key words: partially saturated, Skempton's coefficient B, degree of saturation, liquefaction 